\title{
Revus
}

Journal for Constitutional Theory and Philosophy of Law / Revija za ustavno teorijo in filozofijo prava

$29 \mid 2016$ :

Models of Legislative Authority, Interpretation, Realism, and Defeasibility Contributions from the 1st Genova-Slavic Seminar in Legal Theory

\section{A legal order's supreme legislative authorities}

\section{CRISTINA REDONDO}

\begin{abstract}
The first part of this article is about the rules that define a legal order's supreme legislative authority. In this first part, the article also dwells on several distinctions such as those between norms and meta-norms, legislative and customary rules, and constitutive and regulative rules, all with the objective of determining which of these categories the aforementioned rules belong to. The conclusion is that the basic rules defining the supreme legislative authorities of every existing legal order are necessarily constitutive meta-norms and have a customary nature. The second part of this article takes into account the different possible contents of the ultimate rules that define legislative authority. On this basis, four models of legal order and legislative authority are distinguished: those corresponding to absolute authority and to moral authority, and those corresponding to the rule-of-law state and to the constitutional state. In this regard, several considerations are offered that, on the one hand, single out the specific notion of authority accepted within the constitutional state and, on the other, offer a specific critique of the theoretical distinction between constitutive and constituted authority. According to the analysis provided in this article, every authority is a constituted authority. In particular, supreme legislative authorities are constituted by customary constitutive norms that fall beyond the reach of the authorities themselves and do not depend on the decision or will of any particular individual.
\end{abstract}

\section{Full text}

\section{Introduction}


1 The first part of this article is revolves around the idea of the norms or rules (two terms I will be using interchangeably) on which basis a legal order's supreme legislative authorities are set up. Following Alchourrón and Bulygin, I will assume that a legal order is a sequence of legal systems. ${ }^{1}$

2 It is therefore in order to clarify how I understand the idea of authority and why I will concentrate on the legislative kind. Legal authorities are agents that have the power to decide for other agents. These decisions are usually made by creating, eliminating, or modifying legal norms, that is, by way of actions that introduce a change in the legal order. However, that need not necessarily be the case. In a strict sense, being a legal authority or exercising legal authority does not presuppose or imply a power to modify the legal order. Authorities seek to guide other agents' behavior while excluding options that restrict their autonomy. In other words, they seek to replace these agents' reasoning in order to decide what they should do on given occasions.

3 For instance, legal authority is obviously being exercised when a legislator enacts a new constitutional or ordinary statute, when the government pursues a political plan, or when a judge adjudicates a case. But it is also exercised when a police officer gives oral instructions or when an official executes an order without creating any new one. In a nutshell, an authority is someone that is allowed to impose a certain course of action, independently of their capacity to bring about a change in the legal order.

$4 \quad$ Legal authorities are usually classified as legislative, executive, and judicial, and it is widely accepted that all of them are essential to the existence of a legal order. Even so, legislative authorities enjoy a very special status. First, by definition, legislative authorities are those formally enabled to bring about changes within the law, and dynamicity is a constitutive or sine qua non condition of every legal order. Second, in a modern legal order, legislative authority can be said to hold conceptual primacy over executive and judicial authority, in the sense that the concepts of executive and judicial authority cannot be understood without presupposing that of legislative authority. In fact, even if so-called executive and judicial organs are not formally subordinate to legislative ones, they logically presuppose the exercise of legislative authority, whose decisions, by definition, they enforce and apply. ${ }^{2}$ Finally, and partly for the reasons just mentioned, legislative authorities reflect and express, in a more direct way than the two other kinds of authority, the deepest moral and political convictions at work in a given society. The way in which a society conceives its legislative authorities is tantamount to the way in which it accepts that power can be exercised over the people. In this sense, in the conception each society assumes of legislative authority lies a key to identifying different kinds of legal orders.

5 Legislative authorities have many important traits. Here I would like to underscore some of them. An authority can be such only in a certain domain. Within that domain, legislative authorities typically enact general, abstract norms (statutes, decrees, etc.) and are always organized hierarchically. ${ }^{3}$ So, in every legal order there will always be one or more legislative authorities that are supreme, at least in the two following senses. (1) Within their domain, they are not subordinate to any other legislative authority. That is, any authority other than the supreme one will either depend on it or be a delegated authority. (2) Within their domain, they have the greatest and broadest power to produce a given type of general, abstract norm. This presupposes that the decisions a supreme legislative authority makes in its own domain will prevail over the decisions made by subordinate ones, and that the powers of any other authority will always be 
narrower than the power of the supreme authority. Supreme authorities cannot delegate any type or amount of power they do not have. In this sense, the limits on a supreme authority are also, a fortiori, the limits placed on all subordinate ones.

Every legal order has a set of ultimate norms or rules (two terms I am using interchangeably) by which its supreme legislative authorities are set up. In this article I will try to show that in light of the way these rules frame such authorities, we can distinguish at least four types or models of legal orders. In doing so, I will defend two main ideas. The first one is that the way in which legislative authority is conceived within the constitutional state is qualitatively different from the way in which it is conceived in a rule-of-law state (Rechtsstaat). The second one is that, in an important sense, in the constitutional state, as in any other kind of state, there are no constitutional authorities. In other words, I will try to show that the theoretical distinction between constitutional and constituted authorities is, in a relevant sense, deeply misleading. Every authority is constituted by the specific rules accepted in a given society.

\section{Criteria of validity}

7 Some very familiar ideas from the theory of legal systems will be taken as given here without being discussed. Among these are the idea that every state is bound to at least one legal order, that a legal order can be seen as a set of norms having a temporal sequence, and that these sets of norms can be understood as a systems. ${ }^{5}$ In turn, a set of elements constitutes a system if, and only if, a specific structure emerges out of the relation among those elements. ${ }^{6}$

In this picture, legal systems cannot strictly speaking change, because any change will bring about a new legal system. And yet legal orders do change over time, whenever a competent authority validly creates, modifies, or repeals a legal norm.

$9 \quad$ In taking this point of view, I would concentrate on two traits of every legal order. The first is that legal orders are dynamic: They can change over time, and these changes come about by the intentional creation, elimination, or replacement of legal norms; in other words, they result from the exercise of a legislative power or authority. The second characteristic of every legal order I will focus on is that the conditions for validly creating, eliminating, or replacing a legal norm (that is, the conditions that constitute legislative power) are set by the legal order itself. That is, a norm is a valid legal norm if, and only if, it satisfies the conditions (or criteria of validity) defined by other norms in the same legal order. A legal order, in other words, can be said to be auto-poietic: It regulates its own production. ${ }^{7}$ This implies that, at least in one of the senses in which the expression can be used, "criteria of validity" are meta-norms concerning the production of other norms. They establish the conditions that have to be satisfied in order for a change in the legal order to be valid. In other words, they are power-conferring norms under which certain agents or organs may act as legislative authorities, that is, authorities empowered to validly introduce, eliminate, or modify other norms. ${ }^{8}$ We will see shortly what kinds of norms these criteria of validity are, but for the time being it will suffice to say that (1) they are meta-norms about the way in which other norms may be produced or eliminated, and (2) they at least establish who it is that has the power to introduce, modify, or eliminate norms in the legal order, that is, who the legislative authority is within the legal order. 
necessarily has a set of "ultimate validity criteria," or meta-norms that define the order's "supreme legislative authorities." On the one hand, these ultimate criteria of legal validity are necessarily present in every original legal system belonging to a legal order (that is, the initial system in the sequence that makes up the legal order), for otherwise this original legal system wouldn't be part of a dynamic legal order. On the other hand, these ultimate criteria will continue to be in place in every subsequent legal system belonging to the same legal order until they are modified or eliminated. ${ }^{9}$ In this way, any change that directly or indirectly meets these ultimate criteria is a valid change within the same legal order, while any change in the ultimate criteria of validity is not a change within the legal order, but a change of one order into another. In other words, when the basic or ultimate conditions of legal validity are changed, a new legal order is brought into being. On this basis, we can say (as many authors do) that the identity and continuity of the legal order depends on the identity and continuity of these ultimate or basic meta-norms that underpin the ultimate legislative authority. ${ }^{10}$

\section{The ultimate criteria of legal validity}

Before turning to the analysis of what kinds of norms these ultimate norms are, I think it is important to point out that there is more than one ambiguity regarding the expression "ultimate validity criteria."

One of these ambiguities can be appreciated by recalling a couple of ideas that Ricardo Caracciolo has clearly analyzed. To begin with, according to Caracciolo, if a set of norms constitutes a system, it will necessarily have some internal (or intra-systemic) criteria of validity and some external (or extra-systemic) ones. This not a thesis that can be argued here in any detail, so it will be taken as correct. But the point is that if a system did not have some external criteria for identifying legal norms, we wouldn't be able to know which norms belong to the system-that is, not without falling into an infinite regress or a vicious circle. To be sure, these external criteria do not properly belong to the legal system, and to that extent they are not, strictly speaking, legal norms. They are neither legally valid nor invalid, precisely because they are the basic criteria for identifying valid legal norms.

The second idea I take from Caracciolo is that in every legal system we have to distinguish between dependent (or derivative) norms and independent (or nonderivative) ones. The former belong to the system because they fulfil some of the internal (systemic) criteria of legal validity. The latter-the ultimate norms in a legal system-belong to the system because they satisfy the external (extrasystemic) criteria of validity.

It follows that when we speak of the ultimate criteria of legal validity or the ultimate meta-norms constituting the supreme legislative authority, it is not clear whether we are referring to some ultimate independent norms belonging to the system or some external or extra-systemic norms. This ambiguity is unavoidable because, for different reasons, every legal system has to have both: some external internal criteria of legal validity and some internal ones. On the one hand, as Caracciolo has shown, the former are necessary if we are to avoid circularity or an infinite regress in identifying legal norms. On the other hand, if we concede that every legal system is part of a dynamic legal order, we must also concede that it necessarily contains some internal criteria of legal validity, that is, some meta-norms establishing the conditions under which it is possible to make valid 
changes within the order. As we have seen, these meta-norms have to at least establish $w h o$ it is that holds legislative authority within the order, for otherwise the order could not be described as dynamic.

In light of that background, there are two senses in which criteria of legal validity can be described as "ultimate":

16 (1) In the first sense we have what might be called ultimate ${ }_{1}$ systemic criteria. These are independent meta-norms about the production of legal norms. They belong in every legal system and establish the basic legal conditions for identifying any derivative or dependent legal norm. Among the things they do, they must at least establish who it is that holds supreme legislative authority.

(2) In the second sense we have ultimate ${ }_{2}$ extra-systemic criteria. They are not necessarily norms, and if they are, they will neither be valid nor invalid legal norms. They are not created by any legal authority, and they establish the basic conditions for identifying a legal order's independent or nonderivative legal norms. That is, they are criteria in virtue of which some norms can be identified as the ultimate ${ }_{1}$ valid norms within a legal system.

Having said that, there is a point that needs to be stressed: As much as validity criteria of the first kind can constitute a legal system's basic or final norms, they are not necessarily the ultimate criteria of legal validity. For, as Caracciolo has

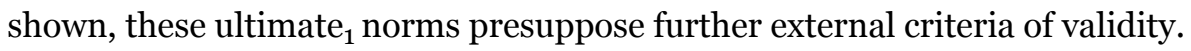

Now, apart from these two kinds of validity criteria (internal and external), a legal system can contain other criteria of legal validity that are not ultimate in either of these two senses. These criteria of validity will be derivative or dependent meta-norms that take part in the system insofar as they have been created in conformity with some ultimate ${ }_{1}$ systemic norms, and so in accordance with ultimate $_{2}$ extra-systematic criteria of legal validity.

20 There is also a further reason why this ambiguity ought to be pointed out. As is usually recognized, the identity and continuity of every dynamic legal order is tied to the identity and continuity of its ultimate criteria of legal validity. If the ultimate criteria, change we will have a new original legal system, giving rise to a different legal order. Accordingly, if the ambiguity is not detected, it won't be clear whether the identity and continuity of a legal order depend on some ultimate internal norms or some ultimate ${ }_{2}$ external factors. Let us set this question aside for the moment and return to it later.

\section{The ultimate norms of an existing legal order}

21 To the extent that our concern is with legal orders in actual existence, if we want identify the kinds of norms that count as the ultimate meta-norms making up the supreme legislative authority, we will have to take into account a contrast between legislated and customary norms.

According to John Gardner, legislative norms have three related traits as follows: ${ }^{12}$ (a) They have an author; (b) they are created intentionally; and (c) they express their content explicitly, whether in an oral or a written formulation. Strictly speaking, this means that every legislative norm necessarily presupposes another norm or set of norms, namely, those which constitute the legislator (the author) that creates it. And, to the extent that this legislator is not a supreme one, they also presuppose the ultimate norms constituting the supreme authority. In 
short, legislative norms cannot exist in isolation. They exist only in relation to another norm or set of norms. This is why many authors emphasize that legislative norms exist only within a system of norms. It would be conceptually impossible to have something like a legislative extra-systematic norm, for that would contradict its own terms. According to Gardner, legislative norms stand in contrast to customary norms, which unlike the former (a) do not have any specific author; (b) are not created intentionally (they may result from multiple intentional actions, but these actions are not deliberately aimed at creating a customary norm); and (c) do not have any expressed form. In this sense, customary norms do not presuppose any competent authority, and their existence does not necessarily require other norms. This means that there can exist social norms independently of any system.

In other words, a customary norm does not depend for its existence on any other norm. On this basis, the extra-systemic existence of a customary norm has to be distinguished from its legal validity, that is, from the fact of its belonging to a legal system. Stated otherwise, the empirical or factual existence of a customary norm, which is always extra-systemic, has to be distinguished from its legal existence, which is always relative and internal to a legal system, that is, it depends on the conditions established by the legal order to which the system belongs.

At any rate, and quite interestingly, if we proceed from these distinctions between legislative and customary norms, we will get a very clear answer to the initial question regarding the kind of norm with which to identify the ultimate meta-norms that shape the supreme authority of the legal order. Whichever sense of "ultimate" we are thinking of (ultimate ${ }_{1}$ or ultimate $_{2}$ ), these kinds of ultimate meta-norms or "criteria of legal validity" cannot be legislative. The very idea of an ultimate legislative norm is a contradiction in terms. Every legislative norm necessarily presupposes a further norm, and for this reason cannot be ultimate. Therefore, the ultimate norms that constitute the supreme legislative authority and ensure the dynamicity of every legal order must be social or customary norms. This is a necessary conclusion, since customary norms are the only kinds of norms that can exist without presupposing other norms.

There are in this regard different positions that we find in legal theory. Many authors, for instance, assert that a legal order's basic meta-norms are internal, systemic norms. Applying what was argued earlier, these norms should have to be characterized as ultimate ${ }_{1}$ within a legal system, and as belonging to it in virtue of the external, extra-systemic fact that they are accepted and followed by the social group. In such acceptance and practice would lie the extra-systemic, ultimate ${ }_{2}$ criteria that, according to Caracciolo, every legal system presupposes. This position should be ascribed to those who reject the idea that legal orders are based on external or extra-systemic rules. ${ }^{13}$ On this view, we only need to recognize certain external facts in virtue of which some contents are accepted as ultimate conditions of legal validity; included among these conditions are those that establish the supreme legislative authorities.

In any case, it should be clear that, even though these ultimate ${ }_{1}$ conditions of legal validity are internal to the system, they are always unexpressed norms, and any intent to express them will be either a more or less successful intent to iterate the already accepted norms or a true or false description of them. In other words, ultimate $_{1}$ conditions of validity must be customary, unexpressed norms-the only kinds that do not presuppose any other norms.

Set in contrast to this position is also a second one that legal scholars subscribe 
to. On this view, the basic meta-norms constituting a legal order's supreme legislative authority are themselves legislative norms. Specifically, they would be norms written into in a constitutional charter. Once again, if we accept the analysis offered here, we can easily appreciate why this position is wrong, for there are two important facts it fails to recognize. For one thing, it fails to see that the idea of an "ultimate legislative norm" is, for the reasons just stated, a contradiction in terms. In whichever of the two senses we use the word ultimate, a legislative norm cannot be ultimate, and an ultimate norm can never be legislative. For another thing, this position is self-defeating, because in accepting that the first constitutional law is the basic (or ultimate) valid norm of the legal order, one thereby also accepts that there must be a further norm (by hypothesis an external one) constituting the authority that laid down that first constitutional law. Otherwise, we wouldn't consider the first constitution as valid law. On this view, in short, we would have to accept that constitutional laws necessarily presuppose some ultimate ${ }_{2}$, extra-systemic norms, which can only be customary norms.

A partial conclusion we can draw at this point is that every existing legal order contains some ultimate (or basic) norms which constitute the supreme legislative authority, and that these norms, whether understood as internal or external, are always unwritten social norms. This amounts to saying that the constitutional power which creates a legal order's supreme authority is always the power of the social group that accepts certain meta-norms about who has the legislative power to create, eliminate, or modify valid legal norms. ${ }^{14}$

\section{The ultimate norms on legislative authority and the rule of recognition}

The idea that a legal system's ultimate (internal or external) norms are necessarily social rules recalls $\mathrm{H}$. L. A. Hart's thesis regarding the rule of recognition. It must therefore be pointed out from the outset that the norms I am referring to do not necessarily coincide with Hart's rule of recognition. ${ }^{15}$ This can be appreciated in the first place by noting that if the Hartian classification of rules were to be applied to the ultimate meta-norms I am talking about, that is, to the power-conferring rules constituting a legal order's supreme legislative authority, these would have to be characterized as rules of change. The interesting point here is that there may be certain kinds of legal orders-purely dynamic legal orders -whose ultimate rules of recognition establish only one condition of legal validity, namely, that a norm has been enacted by a certain individual or organ. In this case, contingently, the rule of recognition is a power-conferring rule, that is, a rule of change.

Apart from these kinds of cases, it is important to see that, given the dynamic character of every legal order, among the ultimate conditions of legal validity we will always find those establishing who it is that may make changes to the legal order, that is, who the supreme legislative authority is. When the will of this authority is not the only sufficient condition of legal validity, or when it is subordinate to the fulfillment of other necessary conditions, it is possible to distinguish two kind of norms: those that identify the authority, and those that identify the other necessary or sufficient conditions of legal validity. In other words, it is possible to distinguish rules of change and rules of recognition. 
In any case, insofar as these are the ultimate rules in the legal order, they must be customary rules. They exist if, and only if, they are accepted and practiced in the social group. In this respect, the relevant attitude on which depends the existence of the ultimate rules of change does not necessarily lie in the official acceptance of rules of recognition, as Hart would have it. Perhaps, the relevant attitude is that of a more or less restricted group. For instance, the acceptance of the judges and citizens, or that of judges of a special kind: a constitutional court. It may also be that the crucial acceptance needed in order for these ultimate rules to be recognized as enforceable is that of a totally different group-perhaps the international community, the armed forces, a dominant social class, or the very same legislative authorities constituted by the rules-while the organs entrusted with applying the law only conform to these power-conferring rules. To be sure, in order for these customary power-conferring norms to exist, they have to be practiced and applied by designated organs, but these organs need not accept such norms.

In a nutshell, in contrast to Hartian rules of recognition, the ultimate criteria of validity identifying a legal order's supreme legislative authority are not duty-imposing rules. ${ }^{16}$ Moreover, if the rules of recognition regulate any behavior, it would not be the behavior of law-applying officials: They would regulate the behavior of the supreme legislator. As we will see, even if the "limits" imposed on the supreme legislative authority can be understood as duty-imposing rules, it should be clear that these duties regulate the way in which general valid norms can be created or changed, not the way in which they should be recognized and applied. Therefore, a plausible speculation is that, in Hartian terms, the rules I am referring do not correspond to those he classifies as rules of recognition. They rather correspond to those that regulate that supreme legislator: ${ }^{17}$ They are the rules that are needed to warrant the continuity and persistence of a legal order. ${ }^{18}$

\section{Power-conferring and regulative meta-norms}

There is an important question that still needs a precise answer: What kinds of norms exactly are those meta-norms that confer supreme legislative power in a legal order? Legal theorists divide into two camps in that regard: Some construe these as constitutive norms, others as regulative norms. The view I will be defending here is twofold: On the one hand, assuming that the difference between constitutive and regulative norms is tenable and significant, I would argue that every legal order's basic power-conferring norms are customary norms having a constitutive nature; on the other hand, however, this kind of constitutive norm can exist only when some regulative norms are in force.

There are different ways in which the meta-norms on the production of legal norms can be classified. According to Guastini, for instance, they should be distinguished into two classes: senso stretto and senso lato (according as they are broadly or strictly understood). The former class includes those meat-norms establishing (1) who has the power to create, modify, or eliminate legal norms, i.e., the meta-norms that create competent legislative authorities, and (2) the procedure through which a given power is to be exercised. In the latter class we should distinguish meta-norms establishing (3) the areas or classes of acts in which legislative power may be exercised and (4) the negative and positive "limits" 
on the normative contents the competent authority is empowered to set. ${ }^{19}$

It is not easy to identify what kind these meta-norms are that frame the supreme legislative authority. It seems clear that those belonging to group (1) are constitutive norms. However, it is not clear if meta-norms establishing procedural conditions and those establishing substantive negative or positive "limits" on authority should be characterized as constitutive or regulative. Hart, for instance, argues that any kind of "limit" concerning the supreme authority should be understood not as an authentic duty but as a lack or absence of power. ${ }^{20}$ If we follow a contemporary scholar like Luigi Ferrajoli, by contrast, there are certain kind of "limits" that can only be understood as genuine duties of the supreme authority. ${ }^{21}$

In my view, the important thing is to note that there is no general, correct answer to this question. It is a contingent matter whether these "limiting" ultimate norms are accepted by the relevant group as framing a sheer absence of power or as establishing an authentic duty. In the first case, they will be seen as part of the norms that define the authority or the type of institutional result they may produce, such as certain kinds of bills, statutes, or decrees. In that case, an authority's failure to respect normative "limits" is not tied to any criticism or reprobation. ${ }^{22}$ Strictly speaking, the "limits" imposed are only necessary conditions for producing a normative result. A failure to observe these "limits" will imply that the result being sought has no legal existence: It is either null or subject to nullification. In the second case, by contrast, the "limits" are conceived as categorical requirements applying to the authority regardless of whether they can also be a necessary condition for producing a valid result. ${ }^{23}$ In short, if Hart is right to distinguish between power-conferring from duty-imposing rules on the basis of the different normative consequences they establish (invalidity and sanctions, respectively), we should conclude, contra Hart, that there are societies where some "limits," even those that bind the supreme legislative authority, are accepted as genuine duties, ones whose violation is connected with reprobation and/or redressive sanctions.

In light of these two possibilities, we can see that there are certain "limit"imposing norms which cannot be understood as norms that merely define the scope of a given power. I am referring to those norms that oblige an authority to act. Under these norms, the behavior of an already constituted authority is no longer optional. They rule out a free decision by the authority because, on their basis, the act of exercising the power in question is no longer discretionary. An abstract example of such kinds of meta-norms on the production of legal norms can be found in those programmatic constitutional principles under which Parliament or Congress is charged with enacting certain norms on a given subject matter or with pursuing a given policy objective. For instance, Article 30 of the Italian Constitution affords full legal and social protections to children born out of wedlock. A quite concrete example would be an administrative law establishing that the authority responsible for security in a university building has to set out an evacuation procedure in the event of fire. These norms can only be interpreted as duty-imposing. Even if the "limits" imposed by these norms are not respected-i.e. the authority in question omits to set forth the appropriate rules-such an omission cannot be interpreted as an intended normative result. This description would be complete nonsense precisely because an omission is not a result that can be invalidated. In this case, the norms the authority fails to comply with do not state conditions for bringing about a valid normative result. They instead state the normative results required from the authority. For this reason, lack of compliance 
can be appropriately described as an act of disobedience or as a violation of a norm.

It is particularly interesting to note that even supreme authorities can be subject to some ultimate duty-imposing norms. In legal orders where that is the case, the ultimate regulative norms "limiting" the supreme authorities contribute to determining how the authority is framed or conceived of within a given society. These norms are not only materially superior to any other norm enacted by any kind of authority, but also have primacy over any other norm from a logical or conceptual point of view. ${ }^{24}$ Being subject to these duties is a constitutive or essential feature of the supreme authority. However, given that these ultimate regulative meta-norms do not spell out a lack of power, the legal norms enacted in violation of them can still be valid or have legal existence. Furthermore, their validity can be challenged and, all things considered, they can be deemed conclusively invalid. ${ }^{25}$ As we will see, this is the case in the constitutional model of legal order where the supreme legislative authority is conceived of as subject to a set of duty imposing meta-norms.

\subsection{A brief digression on different kinds of norms: constitutive versus regulative}

As we have just seen, the negative and positive "limits" on legislative power can be seen either as fragments of power-conferring norms that constitute legislative authority or as regulative norms presupposed by the same power-conferring norms. It is convenient to take a brief pause at this point and reflect on the relation between constitutive and regulative norms.

Following John Searle, the existence of states, legal orders, legislators, legal norms, and so on, can be cited as an example of so-called "institutional facts" or "social reality." ${ }^{26}$ One of Searle's most important contributions has been his analysis of the mechanism through which a social group gives rise to this kind of "reality." In his view, this mechanism consists in the acceptance of a constitutive rule having the following structure: "In context $\mathrm{C}, \mathrm{X}$ counts as $\mathrm{Y}$." In addition to that, Searle distinguishes between constitutive and regulative rules. There has been a lot of discussion about the possibility of reducing constitutive rules to regulative ones. But this is not the time to enter into that discussion.

The point to be emphasized here is instead that the constitutive rules or norms Searle is primarily thinking of seem not to be intelligible independently of any regulative ones ${ }^{27}$. Take, for instance, a favorite example of Searle's, that of money. The accepted constitutive norm says: "In circumstances $\mathrm{C}$, the piece of paper $\mathrm{P}$ counts as money M." This kind of constitutive rule exists as a customary social practice. That a given piece of paper functions or counts as a means by which to pay for something is a fact constructed and maintained through a social group's beliefs and behaviors. In other words, the constitutive rule of money exists if, and only if, as a matter of fact, in the appropriate circumstances $\mathrm{C}$, the piece of paper $\mathrm{P}$ effectively counts as money, that is, as a means by which to pay for something.

This means that the constitutive rule of money would not exist unless, in the relevant social group, there also exist some regulative rules-that is, unless some rules are in force like "It is permitted (for citizens) to pay debts with this kind of piece of paper P" or "It is obligatory (for the government) to accept this kind of piece of paper $\mathrm{P}$ as a means for discharging debts." For this reason, we can say that even if, from a theoretical point of view, it could be useful and justified to 
distinguish between two kinds of norms, in order for a constitutive rule to exist as a social rule, it is necessary that some appropriate customary regulative rules also exist. The two kinds of rules are interconnected. ${ }^{28}$ The existence of the constitutive social rule of money seems to be only an epiphenomenon of the existence of some regulative rules permitting, prohibiting, or requiring certain types of conduct.

The relation between constitutive and regulative norms has been deeply discussed among philosophers. An example of this debate can be seen in the still vivid disagreement among legal philosophers regarding the constitutive or regulative status of Hart's rule of recognition. Be that as it may, the only point I would like to make in this regard is that if we concede that in every existing legal order there is an ultimate social rule of recognition regulating the behavior of law-applying officials, we are thereby also conceding that (1) in every existing legal order there is an ultimate social rule constituting legislative authority, and (2) the two kinds of rules (those conferring legislative power and those regulating the recognition and application of valid norms) are interconnected, however different they may be. We wouldn't have something like a supreme legislative authority if there were no rule of recognition, that is, if there were no group of judges recognizing some persons as the supreme legislative authorities; at the same time, however, to the extent that judges are understood as law-applying authorities in a dynamic order, the existence of a rule of recognition presupposes that there be some "supreme legislative authorities" authorized to create the valid norms that judges recognize as binding. And this is true even if the two powers (the power to create norms and the power to recognize and apply them) are concentrated in the same organ or individual.

\subsection{Two kinds of constitutive norms, two kinds of social reality: the unintentional and the intentional creation of social reality}

As we have seen, sticking to the example of money, money exists and will continue to exist so long as we accept a constitutive rule under which "In certain circumstances $\mathrm{C}$, some piece of paper or metal counts as money." I now want to emphasize that if something, like money, is part of a living, existing social reality, its existence is based on an accepted and practiced constitutive rule, that is, on a customary, social rule we may not even be aware of. I stress this point because -alongside these kinds of constitutive norms whose existence is equivalent to, and indistinguishable from, the effective existence of the institutional facts or entities they constitute-there are also constitutive norms of another kind, namely, legislative constitutive norms, whose existence is itself part of the social reality but which, insofar as they can be ineffective, only guarantee a sort of "formal" but not effective existence of the institutional facts or entities they aim to create $^{29}$.

Contrary to Searle's view, it seems plausible to acknowledge that different examples of social reality are the result of collective unintentional actions. No doubt, there is no shortage of examples of collective intentional actions, as when an orchestra plays a sonata or a legislator enacts some statute. ${ }^{30}$ But it is also true that, individually or collectively, we can do things we do not intend to do. That is precisely the case with social rules, be they regulative or constitutive. Customary rules are the kind of thing we create unintentionally, that is, without a specific 
intention to create a customary rule. In my view, that we can create and maintain institutional facts or entities in a nondeliberate way is something Searle implicitly recognizes when he concedes that some social institutions-always the result of accepting constitutive rules-are even more solid and enduring when the people who generate and sustain those institutional facts or entities are not even aware that they are the ones generating and sustaining them through their attitudes and behavior. ${ }^{31}$

Of course, when we become aware of the mechanism through which we bring about different types of institutional facts or entities, we can use that mechanism intentionally to create new such facts or entities. We can intentionally constitute some "social agents," "organs," or "legislative authorities" that, in turn, and under certain conditions, can intentionally create other specific constitutive norms. In other words, we can intentionally reproduce the social world by deliberately enacting new constitutive norms. To be sure, such new constitutive norms are not spontaneous customary ones. They are legislative norms whose existence or validity depends on the fact that the created "organs" or "legislative authorities" satisfy the conditions established for creating them successfully.

This possibility requires a distinction between two significant kinds of social reality (two kinds of institutional facts) that can be termed effective and formal social reality. Legislative norms, whether constitutive or regulative, are necessarily part of the formal social reality, and it is contingent that they become an effective social reality. For instance, in Argentina, the legislative norm that constitutes the popular juries has been valid-i.e., has existed as a formal institutional fact-since 1853, when it was enacted. However, it was comparatively recently that these juries were actually summoned and became an effective social reality. So it is important to mark this sort of division within the so-called social reality. Legislative constitutive norms are examples of a formal social reality through which we aim to create an effective social reality. Unfortunately, we do not always succeed in doing so. In the same way, multiple other examples of legal institutions -among which legal duties, rights, and powers-only have a formal existence, not an effective one.

In light of the foregoing discussion, we appreciate the ambiguity of expressions like "the existence of an institutional fact," "social reality," or "constitutive rule." In some cases, constitutive rules, like many other examples of social reality, are unintentionally created customary rules: They exist as an effective social practice. In other cases, constitutive rules are deliberately created norms that can be said to be "existent" or "valid" just because they have been properly enacted by the legislative authorities authorized to create them. The social entities of the first kind exist within a group because certain beliefs, attitudes, and behaviors prevail within the group. By contrast, social entities of the second kind will exist or be valid even when they fail to win acceptance within the group in question. They exist not because they are accepted but because the conditions for creating them have been satisfied. As the example of popular juries in Argentina shows, legislative constitutive norms may bring about valid, or formally existent, yet ineffective authorities. By contrast, when these meta-norms succeed in constituting an effective de facto authority, they become customary norms as well, that is, norms actually accepted and followed by the group. If this was not the case, the authority they intend to constitute would not exist as an effective de facto authority.

49 At this point we can draw three further partial conclusions. First, every actually existing legal order (by definition a dynamic order) is based on some meta-norms 
that define the supreme power to enact norms. Which is to say that every existing legal order is based on some constitutive norms that define the supreme legislative authority. Second, these basic constitutive norms cannot be created by a further authority. Which is to say that they cannot be legislative but must be customary or social norms. And third, the existence of these social norms that constitute the supreme authority presupposes that certain regulative norms be in force. Among others things, the social norms that constitute the supreme legislative authority presuppose the existence of a customary norm imposing the duty to recognize that authority, and hence to apply the norms enacted by it.

\section{Four models of legal orders and legislative authority}

50 The ultimate meta-norms constituting a legal order's supreme legislative authority express the political conception effectively accepted within a given society. In what follows I will present four models of a legal order based on four different ways in which the ultimate meta-norms about the production of legal norms constitute the supreme legislative authority. These models are not exhaustive: They show only some of the possible ways in which legislative authority can be conceived.

\subsection{The model of absolute authority}

51 On the first conception-call it the model of "absolute authority"-a legal order's basic meta-norms consist entirely of constitutive rules that place the creation of any other norm or meta-norm in the hands of the authority they constitute, and this includes those norms that govern the authority's own institutional behavior. This means that, on this model, the basic constitutive norms do not impose any regulative requirement among the conditions for an authority to count as such. The conditions for becoming an authority can be biological, historical, economic, and so on, but they cannot include a requirement that any kind of duty-imposing rule be accepted, much less obeyed.

This kind of authority certainly can limit itself by establishing different kinds of restrictions on its own behavior or even by pledging to exercise its authority, that is, by creating programmatic norms. However, because all legal norms, except the rules that constitute them, depend on the will of that authority, the same authority may also exercise the option of ridding itself of those restrictions. In other words, on this model, legal norms imposing any kind of duty are always derived and legislated by a constituted authority, whether subordinate or supreme.

The legal systems corresponding to this model may accept the model either explicitly or implicitly by way of legislative norms. They may do so, for example, by way of a constitution expressly providing that the supreme authority is not bound to either accept or actually comply with any normative restriction. It must be remembered, however, that when a society is effectively governed by this model of authority, that is not in virtue of a legislative norm but rather in virtue of those (independent or extra-systemic) rules that are actually accepted..$^{22}$ In this case, these basic rules impose what Hart calls a model of "continuing omnipotence." ${ }^{33}$ In other words, they constitute an authority whose sovereignty 
cannot at any time be limited. As noted, the supreme authority in this type of legal order could decide to limit itself, but it cannot impose those limitations on its successors, who enjoy the same unlimited power that previous and subsequent supreme authorities likewise detain. In short, the central characteristic of this kind of authority, under the accepted meta-norms that define it, is that it is not subject to regulative rules.

\subsection{The model of moral authority}

54 On the very opposite end of the spectrum is what could be described as the moral conception of authority. On this view, the supreme authority is constituted by a meta-norm which, among the conditions for that authority to qualify as such, includes the requirement that the authority both accept and respect certain regulative rules. Thus, an authority cannot be such unless it complies with certain duties. Only a just authority is an authority. This means that the norms imposing those duties are not created by the authority itself. On the contrary, they are preconditions that must be met in order for any body to become an authority and exercise authority. They are norms of a higher order that are presupposed by the meta-norms that define the authority in question. On this view, in other words, the rules constituting the authority are not independent of the regulative rules to which the authority is subject. Not only can the authority not rid itself of these regulative limits but, as a matter of fact, it cannot choose to flout them, for if it did it would by assumption cease to act as an authority.

Interestingly, if the authority decided to make legislatively explicit the legal norms it is subject to, it would only be reiterating the presupposed duties it is already bound by. As much as this explicitness may certainly be very valuable from a strategic, political, or symbolic point of view, the model does not depend on such legislated norms. If the meta-norms that are indeed accepted made up a moral conception of authority, the authorities could only formally promulgate or abrogate the regulative duties or norms that limit them. However, they would lack the power to introduce them in the legal order or eliminate them from that order. ${ }^{34}$

56 In this case, the basic meta-norms foreshadow a type of authority which, unlike the previous one, exemplifies a model of "continuing subjection." In contrast to the paradigm of absolute authority-on which the supreme authority retains its omnipotence at all times and cannot limit its successors-this model establishes an authority that is subject to permanent limits it cannot remove, either for itself or for its successors.

\subsection{The rule-of-law model of authority}

Between these two extreme conceptions, there are two intermediate views. One of them is usually associated with the so-called rule-of-law state (Rechtsstaat). In this case, the legal order's basic meta-norms (whether conceived as extra-systemic criteria or as independent norms) constitute a supreme authority with limited power. On this model, in other words, different kinds of conditions are imposed, whether for becoming an authority or for exercising the conferred power. As much as these conditions certainly could be accepted as regulative limits, that is not, under this model, mandatory. Strictly speaking, all these conditions are seen as a 
mere absence of power, that is, as guidelines delimiting the power the authority always exercises with discretion and absolute freedom.

A legal system that adheres to this conception of authority will very likely contain legislated norms explicitly stating the limits by which every authority is directly or indirectly bound, ${ }^{35}$ such as a formal, written constitution. However, as previously noted, it is important not to confuse these legislated norms, created by a supreme authority, with the social norms constituting the supreme authority. These two types of norms may be substantially identical because the supreme authorities may pass constitutional laws reiterating the content of the social norms by which the selfsame authorities are constituted. Even so, the difference between these norms remains crucial. The supreme authority could strike out the constitutional norms it itself enacts, but it cannot strike out the social norms that constitute it. This is true of all types of authorities: No authority has the power to revoke the limits imposed by the constitutive social norms that confer the power at its disposal. On the absolute authority model, the supreme authority can lift all its limits merely because, by virtue of the social rules by which it is constituted, those limits are fully dependent on it. This authority is, conceptually, an unlimited authority. In this case, by contrast, in virtue of the rules that define the supreme authority, its power is conceptually subject to the satisfaction of certain positive or negative restrictions. In other words, the actions of this type of authority are valid only to the extent that it meets certain conditions.

Assuming that this is the kind of model in force, as against the moral authority model, if the supreme authority did not respect the limits by which it is bound, its behavior would not strictly amount to an act of disobedience: It would merely be a null or annullable act which fails to produce the desired effects. Moreover, if the authority decided to repeal the constitutional provisions setting forth limitations, that behavior would amount to a mere act of formal repeal. Clearly, the exception is the case of a revolutionary act that in point of fact changes the model or acknowledges a change that has already taken place.

\subsection{The constitutional model of authority}

The last model of authority that could be incorporated in a legal system is the so-called constitutional state. In this case, the basic meta-norms configuring the supreme authority confer not only limited powers on the authority itself but will also confer rights on its addressees. It follows that the supreme authority is subject to correlative duties. Under the meta-norms that configure this model, individuals are entitled to so-called "fundamental" rights. Among other things, this means that those rights do not depend on the authority but, on the contrary, impose restrictions on its behavior. Those rights and duties are the contents of higher-order norms. They are presupposed by the norms that constitute the supreme authority and are accepted by the authority itself. Arguably, under this paradigm, the authority is viewed as holding not only a position of competence-a set of powers-but also a bundle of positive and negative normative positions (a set of rights, immunities, and privileges, while also being subject to duties and areas of noncompetence) correlative to another bundle held by those who are subject to that authority. ${ }^{36}$ As stated earlier, being an authority or having authority can be analyzed in terms of the relationship established between those who exercise authority and those over whom authority is exercised. What is interesting to note in this regard is that, insofar as the limits on the supreme 
authority depend on their addressees' fundamental rights, they cannot be understood only as an absence of power but must also be understood as the content of authentic duties.

As with any other model, the supreme authority set up under the constitutional state cannot rid itself of the limits or features by which it is defined; if it did, it would cease to be an authority under that paradigm. What is peculiar about this type of authority is that its defining features include its being limited not only by higher-order norms restricting its powers, but also by duties and prohibitions regarding the manner, content, and/or circumstances under which those powers can be exercised. Specifically, that authority is duty-bound in all cases where its addressees hold a fundamental right.

It does not follow from what has been said so far that the supreme authority necessarily respects the limits imposed by the fundamental individual rights. The only thing that follows is that the duty to respect those rights is part of the conception of authority under this paradigm. No authority can hold itself out as such while denying these normative limits. If it did, it would be presenting itself not as an authority but merely as a power-holder. This last characteristic is important because it makes it possible to distinguish this conception of authority from that which I have referred to as the "moral" conception. On the present model, an authority is not necessarily just. Being an authority only implies acceptance of the duty to respect the fundamental rights ascribed to its addressees. It does not imply actual compliance. At the same time, as previously stated, these rights are fundamental precisely because they are conceived as constitutive and indefeasible limits of every authority. Accordingly, all exercise of authority under this paradigm is conceptually tied to the claim that such exercise is compliant with these higher-order duties/rights.

From this point of view, the supreme authority is conceptually linked to two kinds of limits: On the one hand are those limits which set out a lack of power, and failing to comply with which normatively entails the nullity/annulment of the results sought by the authority; on the other hand are those limits which correspond to fundamental individual rights (correlative to duties imposed on the authorities), and disregarding which normatively warrants a justified criticism. ${ }^{37}$ As we have seen, the latter limits are regulative requirements which the authority in question accepts, but which it could disregard without ceasing to act as a competent authority, given that compliance with them is not a condition for its competence. This caveat thus calls for a distinction between two ways in which the norms created by this type of authority can be said to be "valid." Because the authority could neglect to effectively comply with the regulative limits (rights/duties) it proclaims to accept, the norms produced within the limits of its competence are only valid pro tanto, and all things considered they could fail to be conclusively valid. Specifically, that will prove to be the case whenever the norms in question frustrate the rights/duties whose acceptance defines this kind of authority. ${ }^{38}$

\section{Some considerations on the constitutional model of authority}

Many contemporary legal systems are characterized by their explicit adherence to the model of authority based on the constitutional rule of law. They do so by 
way of legislated norms, that is, by enacting a formal constitution or a set of norms having a constitutional status (and which are incorrectly considered to be the legal order's ultimate norms). These fundamental laws explicitly state the conditions that must be satisfied in order for supreme legislative power to be held and exercised, and among these conditions is the requirement that the constituted authority accept a set of negative and positive duties by which it is bound. In that sense, these systems attempt to explicitly state the conditions for the validity of its legal norms, and to that end they necessarily appeal to two different types of norms. On the one hand are those norms that expressly delimit the scope of the aforementioned supreme legislative power. These are constitutive norms, and failure to comply with them-which could not be described as "violating" them-necessarily entails the nullity of the intended results. On the other hand are those norms that regulate conferred power. These are prescriptive norms, and failure to comply with them does not deprive their results of legal existence. As with all regulative rules that impose permissions, prohibitions, or obligations, their violation warrants reproach or even entails a redressive duty. Nevertheless, given that acceptance of these regulative norms is a constitutive condition of authority, even if that is not made explicit, their violation justifies the subsequent annulment of the existing results.

Therefore, on this legal model, although the norms that regulate the supreme legislative authority are not constitutive norms, they are constitutively relevant. In general, the conditions they impose are rigidly protected by legislated norms having a constitutional nature, in that they are understood as being completely beyond the reach of the authority's power, or as amendable only by way of special procedures. The existence of these special procedures, and/or the explicit recognition of the impossibility of modifying these conditions, can be seen to indicate that this kind of authority is at least partly aware of what, in reality, is true of any authority, namely, that it is subject to a set of constitutive conditions which the authority itself does not have the power to change. On the constitutional model, in other words, the supreme legislative authority seems to be aware that its "being an authority" is not a natural property but rather a status that is always constituted by prior acceptance of norms that do not depend on the authority itself (strictly speaking, by acceptance of meta-norms that confer power under certain factual or normative conditions).

Laws having a constitutional status are no doubt documents of crucial political importance, so much so that, as we have seen, according to some authors, they would render further social basic norms redundant. ${ }^{39}$ However, from the analysis presented in this work, the kind of error made in taking these positions should be clear. There are two possibilities, and neither seems satisfactory. The first is that these positions disregard that the validity of a constitutional law necessarily presupposes some other norm that confers the power for its valid enactment. If we are to avoid a vicious circle, this latter norm cannot be issued by the same authority that creates constitutional laws, and if we are to avoid an infinite regress, they cannot be created by a subsequent authority, either. The second possibility is that such positions take a highly controversial view that turns out to be self-contradictory. According to this view, even when constitutional laws are legislated norms, they are neither valid nor invalid. Formal constitutions or, in general, laws having a constitutional status would become extra-systemic laws. ${ }^{40}$ Unfortunately, as we know, the idea of an extra-systemic legislated norm is a contradiction in terms.

An additional argument showing why norms on the supreme authority cannot 
be characterized as "extra-systemic" when included in so-called constitutional laws is as follows: That these pieces of constitutional legislation identify the supreme legislative authority and establish ultimate criteria of validity is only contingently true, and will be so to the extent that such constitutional laws correctly replicate the content of those criteria that are in fact accepted. The existing model of legislative authority depends on the paradigm that is effectively in force, and not on the one declared to be so by the competent authority. In this regard, as noted, any linguistic formulation of the meta-norms that define and regulate an existing legal order's supreme authority will be a valid or invalid norm in the system, or it will be a descriptive statement whose truth or falsity will depend on the content of the meta-norms that are in fact in force. In short, the norms that constitute a legal order's supreme authorities are social rules, not explicitly enacted ones. And this fact remains unchanged even when the same authorities enact "constitutional" laws attempting to make the content of such norms explicit.

By appreciating that the basic constitutive rules of any legal order in force are customary, we can explain why their content falls beyond the will of the constituted authority. This is something similar to what Luigi Ferrajoli terms "the realm of the undecidable." ${ }^{41}$ In fact, the content of these rules, as with all customary rules, can change only unintentionally: Such change cannot result from an intentional decision. ${ }^{42}$

69 On this analysis, the claim that the constitutional legal order sets up a new paradigm as compared with the rule-of-law state is in a sense unquestionable. On the constitutional model there are two kinds or categories of legal norms: the ordinary ones introduced through the exercise of legislative authority, and the higher-order norms that constitute the supreme legislative authority and regulate its behavior. In turn, in order to account for the higher-order meta-norms of the constitutional paradigm, we have to distinguish between two types of norms, which should not be confused even though they are necessarily related: On the one hand are norms that confer power and establish the conditions for its successful exercise (constitutive norms in a strict sense); on the other hand are those norms that establish regulative requirements. One thing that could cause these two types of norms to be confused is that, on this model, accepting (albeit not complying with) a set of regulative norms is a constitutive feature of authority: It is part of its defining conditions.

70 In short, unlike the case of the rule-of-law state, legislative authority on the constitutional paradigm is conceived in such a way as to require the concept of regulative higher-order meta-norm or higher-order obligation. These duty-imposing norms are those that establish the fundamental rights/duties that are presupposed by the constituted legislative authority. Certainly, the specific content of the norms that regulate the behavior of the authorities (i.e., the content of fundamental rights/duties) is not something the model can establish. This content is relative to each legal order and depends on the specific rules that are accepted at a given time and place.

71 As noted, this model could be presented differently, that is, by laying emphasis on the necessary flip side of the higher-order duties by which every authority is bound. In this case, we could say that under the constitutive rules of this paradigm, every individual is defined as necessarily bound by certain rights (powers, claims, immunities, privileges) that cannot be renounced, meaning that they are inalienable. This idea enables us to account for another essential feature of this type of legal order. Which is to say that these orders are not merely 
dynamic: They do not consist only of norms issued by competent legislative authorities but also of all norms that, without any intervention by an authority, can be directly derived from the fundamental rights/duties. Even so, it should be clear that on this model of a legal order, the only criterion for making changes by which to introduce a new system in the sequence that makes up the legal order still lies in the will of the authority. This is so even when that will is limited by the higher-order rights/duties that prevail whenever the will of the authority collides with them.

Another notion the present account helps to clarify is that of fundamental rights, whose acceptance is constitutive of legal authority. These fundamental rights cannot lie (or cannot just lie) in the content of legislated norms, even when these norms are protected and guaranteed by way of special reform processes. The status of these fundamental rights/duties is given above all by accepted social rules whose content the legislative authority can contribute to establishing, maintaining, or modifying, but which it cannot create or repeal at will. The act of introducing fundamental rights/duties having a constitutional status (thus attempting to prevent the system's authorities from changing them) can be viewed as a more or less effective attempt to influence the causal process aimed at preserving the basic social rules that are accepted. If these basic regulative limits (i.e., the fundamental rights) were only the content of legislative norms, deliberately created by a legislative authority, they would not constitute limits on that legislative authority; on the contrary, they would depend on it, as is the case within the rule-of-law model of authority.

The latter argument makes plain that the mere presence of rigid and protected constitutional texts recognizing so-called fundamental rights/duties in no way presupposes or implies that the constitutional model of the legal order is in force. The basic rules that are in fact accepted can, within certain limits, empower certain authorities to specify the content of fundamental rights/duties. However, whether or not these authorities are subject to these higher-order duties, or whether or not individuals are entitled to certain inalienable rights, will depend on the basic social rules that are actually followed, not on what the formally enacted laws say, not even if they are termed "constitutional" or "fundamental."

What the authorities can do intentionally is change or repeal constitutional charters or ordinary laws that contain a specific model of authority. In such cases we have two possibilities. If the constitutional model is indeed in force, the repeal of legislated norms enshrining fundamental rights/duties will constitute a violation of effective social rules, and will in that sense be seen as an illegitimate or unjustified move. The alternative is that, in repealing these legislated norms, the authorities are merely making explicit a change that is already taking place. In this case, we would indeed find ourselves before a new model of authority and of the legal order, not by virtue of the repeal per se, but because the repeal reveals a change in basic social rules that is already underway.

As we have seen, formal constitutions or norms referred to as "constitutional" are typically present in states that follow this model. But that need not be the case. What defines this type of legal order is the constituted authority's explicit recognition of two things: Its constituted nature and normative limitations. On this new paradigm, "being an authority" could be said to be a normative position in two different senses. In a first sense, it is such because, as with all remaining cases, "being an authority" is a property attributed by power-conferring norms, regardless of the kind of authority or its scope. In a second sense, it is a normative position because, in this specific case, the authority is constitutively subordinate 
to the acceptance of a set of regulative norms.

From this point of view, a novelty of the constitutional legal order lies precisely in the fact that the supreme legislative authority accepts and conceives of itself as an authority that is limited by the higher-order norms that justify its existence and do not depend on the authority itself. Even more emphatically, the constitutional model could be said to presuppose a sort of judicialization of the supreme legislative authority: Just as a court creates new norms-but at the same time also identifies and interprets the general norms which it is deemed to be bound by, and which justify the individual norms it creates-so, on the constitutional model, the supreme legislative authorities also present themselves as performing these two functions. For on the one hand they create norms that are addressed at individuals who are subject to its authority, but at the same time they make explicit and interpret the norms that justify their existence and guide the exercise of their authority. These characteristics explain why, when this kind of authority identifies fundamental rights/duties having a constitutional status, it views itself as recognizing its preexisting limits, and not as creating rights/duties ex nihilo.

It is true that not all conceptions of authority are aware of the fact that "being an authority" is a normative property, one that ultimately depends on socially accepted norms. However, it is an unchallenged tenet among legal theorists that the existence of authorities is part of a social reality constructed through the acceptance of constitutive rules. In that sense, it is interesting to observe, among other things, that this reveals the misleading, if not incorrect, character of an already classic distinction bearing on this issue, namely, the distinction, and contrast, between constituent and constituted authorities. Many differences can certainly be established among various types of authorities, but once it has been noted that the status of "authority" depends completely on the rules that are accepted within a social group, we could tolerate the distinction only if, at the same time, we make explicit something that it tends to hide: that so-called "constituent" authorities are not alternative to constituted ones but are themselves constituted authorities. Regardless of which model is accepted, if we concede that authorities exist only as part of the socially constructed reality, the notion of a constituent authority must be abandoned for reasons of coherence, given that the only constituent power of authorities (or any other example of institutional reality) is the social group to the extent that it accepts certain constitutive rules.

\section{Bibliography}

Carlos E. ALCHOURRÓN \& Eugenio BULYGIN, 1971: Normative Systems. Vienna/New York: Springer (Library of Exact Philosophy).

Carlos E. ALCHOURRÓN \& Eugenio BULYGIN, 1991: Sobre el concepto de orden jurídico (1976). Carlos E. ALCHOURRÓN \& Eugenio BULYGIN, 1991: Análisis lógico y derecho, Madrid, Centro de Estudios Constitucionales, pp. 393-407.

Eugenio BULYGIN, 1991: Algunas consideraciones sobre los sistemas jurídicos, Doxa (1991) 9: 257-280.

Ricardo CARACCIOLO, 1988: El sistema jurídico. Problemas actuales, Madrid, Centro de Estudios Constitucionales.

Ricardo CARACCIOLO, 1996: Sistema Jurídico. El derecho y la justicia. Enciclopedia Ibero Americana de Filosofía. Eds. Ernesto Garzón Valdés y Francisco Laporta. Madrid, Trotta. 161-176.

Luigi FERRAJOLI, 1989: Diritto e ragione. Teoria del garantismo penale, Roma-Bari: Editori Laterza. 
Luigi FERRAJOLI, 2007: Principia Iuris. Teoria del diritto e della democrazia, Teoria del diritto, Roma-Bari, Laterza.

Luigi FERRAJOLI, 2011: Constitucionalismo principialista y constitucionalismo garantista, Doxa (2011) 34: 15-53.

Jordi FERRER BELTRÁN \& Jorge L. RODRÍGUEZ, 2011: Jerarquías normativas y dinámica de los sistemas jurídicos. Barcelona, Marcial Pons.

John GARDNER, 2012: Some Types of Law. John GARDNER, 2012: Law as a Leap of Faith, Oxford, Oxford University Press, 54-88.

Riccardo GUASTINI, 1997: Gerarchie normative, Materiali per una storia della cultura giuridica, XXVII, No. 2: 463-486.

Riccardo GUASTINI, 1999: Distinguiendo. Estudios de teoría y metateoría del derecho. Barcelona, Gedisa.

Riccardo GUASTINI, 2001: Lezioni di teoria costituzionale. Torino, Giappichelli.

Riccardo GUASTINI, 2006: Il diritto come linguaggio. 2nd ed. Torino, Giappichelli.

Riccardo GUASTINI, 2006a: Lezioni di teoria del diritto e dello Stato. Torino, Giappichelli. Herbert L.A. HART, 1961: The Concept of Law. Oxford, Clarendon Press.

Wesley N. HOHFELD, 1923: Contributions to the Science of Law. Italian transl. by Angelo Pichierri and Mario G. Losano, Concetti giuridici fondamentali, Torino, Einaudi, 1969.

Hans KELSEN, 1960: Reine Rechtslehre. Spanish transl. by Roberto J. Vernengo, Teoría pura del derecho, México D.F., Universidad Autónoma de México, 1979.

José J. MORESO \& Pablo E. NAVARRO, 1992: Algunas consideraciones sobre las nociones de orden jurídico y sistema jurídico, Análisis Fỉlosófico (1992) 2: 125-142.

Corrado ROVERSI, 2012: Sulla duplicità del costitutivo. Ontologia e analisi del diritto: Scritti per Gaetano Carcaterra. Eds. Daniele Cananzi and Roberto Righi, 2012, in Milano: Giuffré. 1251-1295

John SEARLE, 1969: Speech Acts. An Essay in the Philosophy of Language. Cambridge University Press.

John SEARLE, 1995: The Construction of Social Reality. London, Penguin Books.

John SEARLE, 2010: Making the Social World: The Structure of Human Civilization. Oxford, Oxford University Press.

John SEARLE, 2015: Status Functions and Institutional Facts: Reply to Hindriks and Guala (2015). Journal of Institutional Economics, vol. 11, no. 3: 507-514

Jeremy WALDRON, 2009: Who Needs Rules of Recognition? New York University Public Law and Legal Theory Working Papers. Paper 128. http://lsr.nellco.org/nyu_plltwp/128. Published in The Rule of Recognition and The Us Constitution. Eds. Matthew Adler and Kenneth Himma, Oxford University Press, 2009.

Bernard WILLIAMS, 1973: Deciding to Believe. Bernard Williams, 1956-1972: Problems of the Self. Philosophical Papers, Cambridge, Cambridge University Press, 136-151.

\section{Notes}

1 Alchourrón and Bulygin 1971.

2 This logical priority would hold even if, from a temporal point of view, a single organ can create and apply a norm at any given moment.

3 Here, the hierarchical relationship is understood as a relation enabling one authority to trump another where conflicts of competence arise. On this matter, see, for example, Ferrer and Rodríguez 2011: 142.

4 I will be using expressions like "criteria of validity," "criteria of legality," and "criteria for belonging to a legal system" interchangeably, and in this practice I am following Eugenio Bulygin, who clearly distinguishes between the criteria a legal system has to satisfy in order to belong to a legal order and the criteria a norm has to satisfy in order to belong to a legal system. Nevertheless, as Bulygin emphasizes, the former criteria partly determine the content of each legal system, and in that sense they also work as criteria for the validity of norms within a legal system. See Bulygin 1991: 265. 
5 See Alchourrón and Bulygin 1971. See also, Bulygin 1991.

6 See Caracciolo 1988: 12. See also Caracciolo 1996: 161-176.

7 See Kelsen 1979: 201-206. This quote corresponds to the Spanish translation of Kelsen 1960.

8 On the subject of meta-norms about the production of legal norms, see, for example, Hart 1961: 91-95. Cf. Guastini 1999: 308-312. I will come back to this point in detail below.

9 On this principle of perdurability (principio de supervivencia), see Moreso and Navarro 1992: $125-142$.

10 It must be stressed that these "ultimate" meta-norms on the production of other norms are necessarily general norms. That is to say, they do not confer powers on a particular authority or organ, but rather set forth abstract conditions that must be satisfied in order for that body to be empowered. That is so on the conceptual assumption (which will not be discussed here) that a legal order is not only dynamic but also continuous and persistent over time. If the ultimate criteria of validity conferred powers on a particular individual or organ, the legal order would certainly be dynamic, as the authority so established would have the power to create new norms and give rise to new systems. However, once that individual or organ disappears, the legal order would disappear along with it, on the assumption that there would be no general rule that could make it possible to identify ex ante who is entitled to succeed to that authority. On the continuity of the legal order, it bears recalling Hart's critique of Austin, highlighting the need for a general norm that confers power on the supreme authority. See Hart 1961: 49-76.

11 One such ambiguity, which shall not be discussed here, relates to the distinction that Norberto Bobbio drew between who has the power to decide, how they are to decide, and what can be decided. It should be noted in that regard that, in certain contexts, the expression "norms establishing criteria of validity" refers to all meta-norms establishing some condition for the production of other norms, without distinguishing among norms stating who can do that, how it must be done, and in regard to what subject matter. On this reading, there is no point in discriminating between rules of change and rules of recognition, because both are "norms establishing criteria of validity," that is, conditions for the production of valid norms. In other contexts, by contrast, norms that state who has the power to produce valid norms are distinguished from those that establish other conditions of validity with respect to how and over what subject matters competence can be exercised. On this second reading, there is a distinction between rules of change (rules conferring powers on an authority) and rules of recognition, that is, rules establishing other conditions of validity. In short, the expression "norms establishing criteria of validity" sometimes makes it impossible to distinguish between rules of recognition and rules of change, placing both in the same category; other times, it refers only to rules of recognition, assuming that power-conferring rules, that is, rules of change, make up an independent category.

12 The contrast I am setting up draws on Gardner's approach but does not coincide with it. See Gardner 2012: 54-88.

13 An example is Guastini 1999: 380, as well as Guastini 2001: 2-3.

14 This idea is consistent with John Searle's thesis regarding the construction of so-called social reality. This is a question we will be returning to shortly.

15 See Hart 1961: 97-107.

16 According to a standard interpretation of Hart's view, the rule of recognition requires officials to apply the rules identified by the criteria of validity included in it. See Raz 1975: 146.

17 See Hart 1961: 72-76.

18 It is important to note that the supreme legislative authority does not have to be concentrated in a single organ or official called the legislator. In many contemporary legal orders this supreme legislative competence is shared by a congress or parliament and a special court or group of judges.

19 See Guastini 2006: 88-93.

20 See Hart 1961: 68.

21 See Ferrajoli 2007: 92.

22 On the difference between norms that establish essential or constitutive conditions for the valid exercise of power and norms that impose a duty, see Hart 1961: 27-35. 
23 Unlike nullity-which is part of the rules establishing essential conditions or constitutive limits for the legal existence or validity of the results that certain actions are aimed at producing-the relative sanctions are not necessarily part of the duty-imposing norms that regulate certain actions. In that regard, see Hart 1961: 34-35.

24 In the language of Riccardo Guastini, these duty-imposing meta-norms would be said to stand in a structural or formal relation of hierarchy relative to the other norms. See Guastini 1997: 470. In my opinion, however, it is misleading to speak of "structural or formal hierarchy." It is appropriate to instead distinguish between the structural or formal relation among these norms and the relation of primacy that can be established when the norms conflict: The latter is a hierarchical relation, the former is not.

25 Luigi Ferrajoli, for example, distinguishes between the effectiveness and the validity of norms, and does so precisely to underscore that norms which violate substantive duties of a higher order are not valid in a legal order. See Ferrajoli 1989: 348-356.

26 See Searle 1995.

27 To be precise, according to Searle, "Constitutive rules constitute (an also regulate) an activity” (my emphasis). Cf. Searle 1969: 34.

28 It should be clear that I am not claiming, as Searle does, that constitutive rules are themselves regulative rules. For instance, I am not claiming that a rule that constitutes a legislative or judiciary authority at the same time regulates its behavior (either permitting or requiring it to exercise the conferred authority). I am instead saying that there can exist a social rule constituting a legislative or judiciary authority only if some other regulative rules are in force that do not necessary guide the constituted authority's behavior. For instance, we cannot say that there is a social rule constituting authority (A) unless some agent (B) is obliged to obey (A). The regulative rule regulates the actions of the agent, not those of the authority.

29 Even if connected, these two senses of constitutive rules do not coincide with those analyzed in Roversi 2012, 1251-92. This is not the place to discuss the multiple distinctions between constitutive rules that have been proposed and their relation to regulative rules.

30 See Gardner 2012: 65-74.

31 See Searle 2010: 107-108.

32 Recall here that there are two possible ways of interpreting the meta-norms that define the supreme authority: These can be understood as either intra-systemic or extra-systemic norms. Under no circumstance, however, can they be legislated norms.

33 See Hart 1961: 146.

34 On the concept of formal derogation, see Alchourrón and Bulygin 1991: 393-407.

35 Recall that the supreme authorities have the highest normative power (the power that trumps all others in the hierarchy). For this reason, the constitutive limits imposed on the supreme authorities are, a fortiori, also limits imposed on all its subordinate authorities.

36 In characterizing the different normative positions which pertain to individuals who are rights-holders, and which correlate to those positions the authority finds itself in with regard to those individuals, it is useful to refer to Hohfeld 1969.

37 On the notion of obligation, see Hart 1961: 84-86.

38 This point cannot be developed in any depth except to note that the distinction between pro tanto and conclusive validity does not correlate with the distinction between formal and substantive requirements.

39 As discussed, this position can be attributed to Riccardo Guastini. Another example can be found in Waldron 2009.

40 For example, according to Riccardo Guastini, "the concept of validity is simply inapplicable to constitutions. A constitution is neither valid nor invalid" (my translation). See Guastini 2006: 103. The same view can be found in Guastini 2006a: 10. In this regard it should be emphasized that, even though Guastini quotes Caracciolo and borrows from him the expression "independent norm" to refer to the constitution, he does so by attributing a different meaning to this expression. According to Caracciolo, independent norms are ones that are valid within the system by virtue of extra-systemic criteria. According to Guastini, "independent," "supreme," or "sovereign" norms are extra-systemic and are neither valid nor invalid.

41 See Ferrajoli 2011: 15-53. Consequently, according to Ferrajoli, the idea of sovereign authority should be abandoned or radically reinterpreted. See Ferrajoli 2007: 854. 
42 On what cannot be done intentionally, see Williams 1973: 136-151.

\section{References}

Electronic reference

Cristina Redondo, «A legal order's supreme legislative authorities », Revus [Online], 29 | 2016, Online since 30 November 2016, connection on 03 December 2016. URL: http://revus.revues.org/3600 ; DOI : 10.4000/revus.3600

\section{About the author}

\section{Cristina Redondo}

Associate Professor of Law at the University of Genoa. Address: Tarello Institute for Legal Philosophy, Via Balbi 30/18, Genoa 16126 (Italy). E-mail: cristina.redondo@giuri.unige.it

\section{Copyright}

All rights reserved 